ISSN 2518-7953

\section{ПРАВНИЧИЙ \\ ЧАСОПИС \\ ДОНЕЦЫКОГО \\ УНІВЕРСИТЕТУ}

№ 1 (37) - 2019

\title{
У HOMEPI
}

Функціональна дісвість механізму правового регулювання господарських відносин

Щодо визначення поняття «права промислової власності»

Впровадження свропейських стандартів у сферу процесуально-правового регулювання цивільного судочинства Украйни 


\section{ПРАВНИЧИЙ ЧАСОПИС ДОНЕЦЬКОГО УНІВЕРСИТЕТУ}

$$
\text { № } 1 \text { (37) - } 2019
$$

Науковий журнал. Виходить двічі на рік

Рекомендовано до друку Вченою радою

Донецького національного університету імені Василя Стуса

(протокол № 1 від 28.08.2019 р.)

\section{Видається з лютого 1997 р.}

Свідоцтво про державну реєстрацію друкованого засобу масової інформації КB № 22584-12484 ПР від 28.02.2017p.

Журнал включено до Переліку наукових фахових видань Украйни, в якихможуть публікуватися результати дисертаційних робіт з юридичних наук

(додаток 7 до наказу Міністерства освіти і науки Украӥни від 28.12.2017 р. № 1714)

\section{РЕДАКЦИЙНА КОЛЕГІЯ}

А. Г. Бобкова - доктор юридичних наук, професор, академік НАПрН України (головний редактор); А.М. Захарченко - доктор юридичних наук, доцент (заст. головного редактора); Р. Ф. Гринюк - доктор юридичних наук, професор; Р. А. Джабраілов - доктор юридичних наук, доцент; В. М. Кампо - кандидат юридичних наук, доцент; І. Ф. Коваль - доктор юридичних наук, доцент; А. С. Краковська - кандидат юридичних наук, доцент; С. П. Мороз - доктор юридичних наук, професор (Республіка Казахстан, м. Алмати); Л. М. Ніколенко - доктор юридичних наук, наук, професор (Республіка Казахстан, м. Алмати); Л. М. Ніколенко - доктор юридичних наук,
професор; Ю. М. Павлюченко - кандидат юридичних наук, доцент; В. В. Рєзнікова - доктор юридичних наук, професор; О. Г. Турченко - кандидат юридичних наук, доцент; В. А. Устименко доктор юридичних наук, професор, член-кореспондент НАН Украӥни та НАПрН Украӥни; . С. Шебетун - кандидат юридичних наук, доцент.

\section{ЗАСНОВНИК}

Донецький національний університет імені Василя Стуса

Адреса редакції: Україна, 21050, м. Вінниця, вул. Грушевського, 2, каб. 105-а +38(067) 925-69-13

law-journal.div@donnu.edu.ua

C Донецький національний університет імені Василя Стуса, 2019

Підписано до друку 02.09 .2019 p.

Формат 70×100/16. Папір офсетний. Друк - цифровий. Умовн. друк. арк. 14,14

Тираж 100 прим. Зам. № 111

Донецький національний університет імені Василя Стуса 21021, м. Вінниця, вул. 600-річчя, 21.

Свідоцтво про внесення суб'єкта видавничої справи до Державного реєстру

серія ДК № 5945 від 15.01.2018 p. 


\section{ПРАВА ЛЮДИНИ, ДЕРЖАВА, СУСПІЛЬСТВО}

Амелічева Л. П.

Гідна праця: теоретико-правовий погляд на проблему іiі регулювання ........ 3

Дудоров О. О., Мовчан Р. О.

Порушення обмежень щодо одержання подарунків:

проблеми кваліфікації та вдосконалення законодавства 12

\section{ПРАВО ТА ЕКОНОМІКА}

\section{Стаднік I. B.}

Функціональна дієвість механізму правового регулювання господарських відносин.

\section{Новошицька В. I.}

Щодо вартості втраченого, пошкодженого або знищеного майна

у складі збитків у сфері господарювання 28

Павлюченко Ю. М., Кочевець А. А.

Правова робота з відшкодування збитків, завданих порушеннями господарських договорів 35

Дорошенко Л. М.

Способи усунення дедлока як різновиду корпоративних конфліктів 45

\section{Павлюк С. М.}

Щодо договірного регулювання перевезення вантажів у прямому змішаному сполученні

Оверковський К. В.

Щодо визначення поняття «права промислової власності» 63 Кулик О. I.

Ознаки стимульованих суб'єктів у сфері виробництва енергії з використанням альтернативних джерел. 


\section{БОРОТЬБА ЗІ ЗЛОЧИННІСТЮ}

\section{Мовчан P. O.}

Щодо антисуспільної спрямованості самовільного зайняття земельної ділянки та самовільного будівництва

(стаття 197-1 Кримінального кодексу України)

\section{Жданова I. $\epsilon$.}

Умови правомірності, що стосуються діяння особи, яка зазнала примусу

(за змістом статті 40 Кримінального кодексу України)

\section{Щербак I. $A$.}

Проблемні аспекти процедури повідомлення про підозру

в контексті реалізації принципу верховенства права.

\section{ШЛЯХИ ВДОСКОНАЛЕННЯ ЗАКОНОДАВСТВА}

\section{Атаманчук I. B.}

Впровадження європейських стандартів у сферу процесуально-правового регулювання цивільного судочинства України

\section{Письменна О. П.}

Щодо правової основи функціонування Національної поліції України ....117

\section{ЗАРУБІЖНИЙ ДОСВІД}

\section{Турченко О. Г.}

Воєнно-політична інтеграція країн в архітектурі європейської безпеки у другій половині XX - на початку XXI століть

\section{ПОДІї}

Всеукраїнська науково-практична конференція «Правове забезпечення інтеграції України в європейський політичний, економічний, безпековий, інтелектуальний простір»

Огляд результатів круглого столу «Забезпечення конституційних гарантій незалежності суддів та єдності юрисдикцій судів як фундамент правової демократичної держави» 